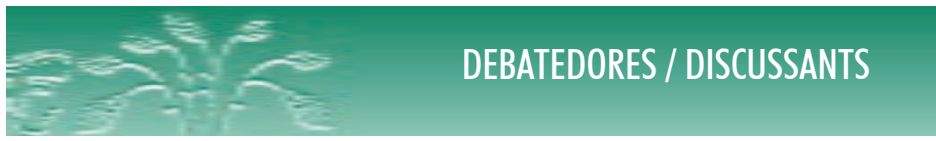

10.12957/demetra.2013.3611

\title{
Por que falar de teoria antropológica clássica no campo atual da alimentação?
}

Why talk about classic anthropological theory in the current field of nutrition?

Madel Therezinha Luz'

Centro Biomédico, Departamento de Políticas e Instituições de Saúde. Universidade do Estado do Rio de Janeiro. Rio de Janeiro, RJ, Brasil.

Correspondência / Correspondence

Madel Therezinha Luz

E-mail:madelluz@uol.com.br
Podemos nos perguntar, ao terminar de ler a densa, coerente e razoavelmente longa argumentação contida no texto do artigo "Estrutural-funcionalismo antropológico e comensalidade: breves considerações sobre a mudança social" de César Sabino e Maria Cláudia da Veiga Soares de Carvalho, se faz sentido ainda falar, nas Ciências Sociais, da abordagem estrutural-funcionalista, seja como modelo, teoria, ou método de análise. Sobretudo se lido a partir dos founding fathers da Antropologia e das variadas correntes teóricas e metodológicas a que deram origem, na segunda metade do século XX, na Antropologia, mas também na Sociologia, na Política e, finalmente (depois dos anos 1970), nessa extensa área disciplinar conhecida como Comunicação Social.

A perplexidade se explica: num universo cultural em que o pensamento científico, inclusive o social, deve estar em constante mudança para mostrar-se afinado com a lógica científica predominante, em evolução contínua ou, se preferirmos o termo da moda, em contínua inovação, embora mudando para que permaneça sempre a mesma epistême, sucedendo-se, em verdadeiro desfile, as teorias em voga num determinado período de tempo - cada vez mais curto, deve ser assinalado - pode soar fora de moda trazer à tona analítica certos fundamentos teórico metodológicos temporalmente inabaláveis do pensamento sócioantropológico. 
A nosso ver, é o caso do estrutural-funcionalismo. Mesmo retraçando sua trajetória de multiplicação em teorias diversas, variadas interpretações e múltiplas controvérsias geradas ao longo do tempo, por toda a segunda metade do século XX, de acordo com as diferentes correntes das disciplinas presentes nas Ciências Sociais, macro ou microanalíticas, esta abordagem teóricometodológica mostra ainda fôlego em densidade conceitual e em profundidade de sua fonte teórica: o estruturalismo funcional. Ou funcionalismo estruturalista, de acordo com o que o olhar analítico privilegie: a morfologia ou o funcionamento das estruturas, isto é, seu movimento processual ou sua estabilidade em termos de forma sistêmica. De qualquer modo, trata-se de uma abordagem estática de totalidades sociais, seja em macro ou micro nível de abordagem metodológica ou de interpretação teórica. Queremos dizer que essas totalidades são sempre vistas, na perspectiva estrutural funcionalista, através de sua constituição morfológica irredutível ("estrutura”), ou através de suas variações processuais no tempo ("mudanças"), isto é, variações no seu conjunto como um todo, ou em suas unidades constitutivas. As variações nas unidades constitutivas das estruturas sociais podem ou não levar a modificações do todo morfológico ("mudanças estruturais"), dando origem a novas formas sociais, por combinação ou desenvolvimento de unidades, em busca de especialização de novas funções, seja devido ao crescimento, ao amadurecimento ou à evolução da complexidade das unidades constitutivas da totalidade em análise. O que, do nosso ponto de vista, identifica a questão da mudança social, no estruturalismo funcional, ao modelo da "variação processual", isto é, a uma "fisiologia" em processo das formas sociais". Morfologia e fisiologia da vida social são a marca por excelência método funcionalista, tanto na Antropologia, como na Sociologia, o que motivou muitas das críticas a este método.

Em outra perspectiva, ou tomando outros ângulos de análise do método, os autores do presente texto, Cesar Sabino, sobretudo, por sua formação sólida em Antropologia, procuram nos mostrar como certas raízes do "significar", cimento do universo simbólico que origina a cultura como dimensão do existir humano, isto é, o atribuir sentidos específicos às atividades humanas básicas entre as quais está, sem dúvida, a de comer, ou de alimentar-se, ou de nutrir-se, tema central do artigo - são formas universais, mesmo que as práticas delas derivadas variem em tempo e espaço sociais diversos. Ou, se preferirmos outra expressão, mais ligada à sócio história, de acordo com diferentes tipos de desenvolvimento histórico das sociedades.

Práticas sociais fundamentais, como às ligadas à reprodução da vida da espécie humana, que originam aquelas que designamos, na cultura contemporânea, de "práticas sexuais", ou as ligadas a sua preservação, como a alimentação e o sono, ou ainda a sua recuperação, como as ligadas à cura, que geram todo o campo de atividades que conhecemos contemporaneamente como saúde,

a Ver LUZ, M.T. Fondéments Idéologiques de la méthode structurelle-fonctionnelle, dissertaçãode Mestrado em Sociologia, Louvain, Université Catholique de Louvain,1969, 157 + XVI p., cap. 1 e 2. Op.cit. no artigo dos autores. 
são investidas não apenas de sentidos e significados importantes para o grupo social, como de práticas, ritos e normas que as ratificam e - mais que isto - asseguram a reprodução daqueles sentidos e significados pelos diferentes grupos humanos e suas culturas.

Certamente, tais práticas sociais, geradas pela "consciência coletiva”, de acordo com Durkheim, pelo fato de se tornarem mandatórias, de gerarem atitudes e comportamentos obrigatórios, não são puras "objetividades", não são uma "estrutura" externa ao sujeito, conforme visão corrente mecanicista, que interpreta a noção de consciência coletiva como se tratasse uma dimensão abstrata da sociedade, quase como um plano geométrico, sem verdadeira consistência social.

É necessário entendermos que a normatividade social gerada pelo conceito durkheimiano de consciência coletiva - depois modificado pelos seguidores que se sucederam, muitos citados no texto do artigo, adotando outras formulações - ou em Malinovski, Levi-Strauss e Bourdieu, ou mesmo em seus posteriores, não é uma dimensão externa ao sujeito humano. Ela é constitutiva da própria pessoa humana, sendo paulatinamente interiorizada nos processos de socialização típicos de cada sociedade, tornando-se o indivíduo humano um sujeito, muito mais que um mero indivíduo de uma espécie animal específica, tida como superior, em grande parte devido a esses processos. Socialização que significa normatividade ou submissão social dos sujeitos individuais.

Certamente, não se pode ignorar as dimensões biológica e psicológica nesse processo de constituição normativa do sujeito humano, nem suas intrincadas e complexas mediações, mas é impossível pensar um ser humano fora do seu contexto cultural de socialização, determinado pela estrutura social específica em que se insere desde seu nascimento. Em vários sentidos, a construção do corpo e das emoções humanas é condicionada pela estrutura vigente. Embora se possa afirmar também que o reverso é verdadeiro, isto é: atitudes e ações coletivas, grupais ou individuais, motivadas por necessidades sociais insatisfeitas dos agentes ou por sentimentos de indignação moral, rejeição política ou, contrariamente, de apoio à ordem social, podem produzir pequenas alterações ou mudanças completas na estrutura social. E a contribuição teórica e metodológica para a compreensão deste processo, através das correntes estruturais funcionais, analisadas no artigo dos autores, e sobre o qual esboçamos esses comentários, é absolutamente inegável.

O funcionalismo morfológico de Malinovski e de Durkheim, assim como a formulação estrutural etnológica de Levi-Strauss sobre a organização e o desenvolvimento das sociedades e da cultura são mais que simples correntes teóricas. São verdadeiros instrumentos metodológicos fundantes dos campos da Antropologia, da Sociologia e da Política. Através dessas abordagens podemos compreender e analisar o que se pode designar como "elementos invariantes" da estrutura, isto é, aqueles que realmente definem uma estrutura social.

A morfologia malinovskiana, assim como a durkheimiana, proporcionam uma abordagem metodológica certamente influenciada pela Biologia de sua época. Por ela, entretanto, é possível analisar elementos básicos constitutivos de cada sociedade, isto é, as "formas constitutivas" sociais e 
suas variações ao longo do tempo histórico, em perspectiva morfológica, de variação praticamente anátomofisiológica, coerente com a Biomedicina. Já na abordagem straussiana, em que a morfologia estruturada da sociedade supõe uma estrutura social inconsciente, os elementosconstitutivos invariantes, isto é, as regras das regras que normatizam cada sociedade, podem estar objetivadas nas normas, cuja função básica é justamente a preservação das regras ocultas na estrutura social objetivada. Nessas regras invariantes da estrutura residem, se assim podemos afirmar, a instância simbólica, o núcleo duro do universo cultural da humanidade, que pode ser narrado implicitamente através de mitos, como nas sociedades indígenas, mas também através das narrativas lendárias, caso das sociedades medievais, ou nas tragédias gregas e modernas (teatro grego, ou shakespeariano), caso das sociedades complexas dotadas de escrita.

Como o comer, ou alimentar-se, constituindo-se em função básica do viver da humanidade, constitui-se também em parte irredutível do universo simbólico humano, o discurso metodológico estrutural funcional é um instrumento teórico e metodológico possivelmente ainda hoje indispensável às análises antropológicas, ou sociológicas fronteiriças com o campo da Nutrição. Será necessário apenas especificar com que categorias, em que versões do método se pretende trabalhar, precisando para quais objetos de pesquisa o método é adequado e produtivo. Consideramos o presente artigo de SABINO e CARVALHO um primeiro grande esforço neste sentido. 